\title{
BENTAZON-MCPA EFFECT ON Fusarium oxysporum ROOT ROT ON Trifolium pratense IN GREENHOUSE CONDITIONS
}

\author{
Ricardo Ceballos $^{1 *}$, Ximena Cofré ${ }^{2}$, Andrés Quiroz ${ }^{2}$, Nelson Espinoza ${ }^{3}$ and \\ Graciela Palma ${ }^{2}$ \\ ${ }^{1}$ Laboratorio de Ecología Química; Instituto de Investigaciones Agropecuarias, CRI-Quilamapu. \\ Av. Vicente Méndez 515, Casilla 426, Chillán Chile. ${ }^{2}$ Departamento de Ciencias Químicas. \\ Universidad de La Frontera. Casilla 54-D. Temuco, Chile. ${ }^{3}$ Instituto de Investigaciones \\ Agropecuarias, CRI-Carillanca, Casilla 58-D, Temuco, Chile. \\ *Corresponding author: rceballos@inia.cl
}

\begin{abstract}
In Chile, the main factor in red clover (Trifolium pretense L.) stand decline is fusariumroot rot, which results in a reduction in yield. Fusarium oxysporum (Schlect.) is the most prevalent pathogen recovered from diseased red clover roots plants. Agronomical management of red clover includes application of broadleaf herbicides such as MCPA and bentazon. This study was conducted to evaluate the effects of bentazon and bentazon/MCPA mixture on phytotoxicity and root rot as caused by $F$. oxysporum on red clover, under greenhouse conditions. In addition, in vitro mycelial growth and conidial germination of $F$. oxysporum was studied. A reduction of $40 \%$ in crown diameter and $57 \%$ shoot dry weight was observed 30 days after treatment with a high rate of bentazon/MCPA and $F$. oxysporum inoculum. The bentazon $-F$. oxysporum interaction reduced root dry weight by $57 \%$ at $1 \mathrm{X}$ rate and $42 \%$ with $2 \mathrm{X}$ rate at 20 and 30 of evaluation. Bentazon caused a significant increase in phytotoxicity at the high rate and the mixture bentazon/MCPA increased root rot severity and phytotoxicity at the high rate. The conidial germination and mycelial growth were significantly reduced by bentazon/MCPA. These results suggest that red clover growth and persistence could be adversely affected by $F$. oxysporum after bentazon and bentazon/MCPA application.
\end{abstract}

Keywords: herbicide, fusariosis, legume, plant diseases, phytotoxicity

\section{INTRODUCTION}

Herbicides are reported to affect the incidence and severity of plant diseases trough their interaction with plants, pathogens or other microorganisms (Heydari et al., 1997; Heydari and Misaghi, 2003). While a number of plant diseases are reported to occur with increased incidence and severity, after the application of herbicides (Altman and Campbell, 1977; Altman and Rovira, 1989; Bollen, 1993; Sanogo et al., 2000), other diseases have shown decreases or no significant changes (Dann et al., 1999; Dissanavake et al.. 1998). 
Fusarium root rot is a common disease in Chilean red clover pastures, as well as in other areas in the world (Ceballos et al., 2004, 2006; Galdames, 1991; Steiner and Alderman, 1999; Venuto et al., 1995), causing reductions in productivity and persistence (Coulman and Lambert, 1995; Leath, 1985; Venuto et al., 1996). Fusarium oxysporum Schldt. is the most common, economically important and studied Fusarium species (Ceballos et al., 2004; 2006; Venuto et al., 1995; Venuto et al., 1999). Fusarium affected plants may exhibit poor emergence, and the resulting seedlings are often stunted and weak. The pathogen penetrates directly through wounds in the plant surface, causing necrotic lesions on lower stems and roots (Carson et al., 1991).Akiyama et al., 2002; Larose et al., 2002; Vierheilig et al., 2002).

Commercial formulation of MCPA [(4chloro2-methylphenoxy) acetic acid)] and bentazon (3-isopropyl-1H-2,1,3-benzothiadiazin-4(3H)-one 2,2-dioxide), are widely used in Chile, and worldwide (AFIPA, 2002; Kuds and Streibig, 2003; Liu et al., 1994) to control broadleaf weeds in red clover. MCPA is absorbed by roots and foliage and translocated into the plant and causes the death of susceptible weeds. It stimulates uncontrolled growth of the meristematic tissues and diminish synthesis of DNA and proteins; thus disrupting basic metabolic processes in plant cells and tissues. While these effects are lethal to susceptible weeds, they may also affect tolerant crops depending on a number of factors (Conrad and Stritzke, 1980). Research on cereal crops has indicated that low concentrations of chlorinated phenoxyacetic acid derivatives may stimulate the rate of root and shoot growth, seed germination and photosynthesis, but the higher concentrations inhibit these processes (Grabinska-Sota et al., 2003; Hess, 1993). MCPA causes stunting, distortion and gall formation on the roots of a number of crops (Tharp and Kells, 2000). Studies on MCPA used for weed control on red clover in Chile indicated that this herbicide had the most detrimental effects on red clover plants (Ceballos et al., 2004). On the other hand, bentazon is a contact herbicide that inhibits photosynthesis by specifically inhibiting photosystem II (Bradshaw et al., 1992; Fleming et al., 1988). The primary mechanism of bentazon action is to compete for the QB binding site with plastoquinone, the electron transporter in photosystem II, resulting in photosynthesis inhibition and generation of oxidative stress in sensitive species (Wu and Wang, 2003). Bentazon has very little long distance systemic activity within the plant and acts directly where is applied and is absorbed primarily by the foliage but also by the roots (Tomlin, 1995). This herbicide is used only as a post-emergency herbicide, for control of annual and perennial broadleaf weeds (AFIPA, 2002).

The phytotoxic effect of MCPA, bentazon, 2,4-DB, flumetsulam, haloxifop-methyl, and of the mixtures usually used on red clover as flumetsulam/2,4-DB and bentazon/MCPA herbicides have been reported (Ceballos et al., 2004). In our study, all the herbicides were evaluated at recommended and twice recommended rate and all caused early foliar damage, but bentazon and bentazon/MCPA produced the greatest shoot damage. Roots were injured from all herbicides, yet usually recovered over time. Bentazon/MCPA induced the most severe root injury, up to $17 \%$ of the plants, and caused seedling death (Ceballos etal., 
2004). In a subsequent study, the influence of MCPA on $F$. oxysporum root rot on red clover showed increased severity of Fusarium root rot on red clover seedlings and phytotoxicity at a high rate (Ceballos et al., 2006). However, there is no information available on the effects of bentazon and a bentazon/MCPA mixture on $F$. oxysporum and their role in the severity of red clover root rot caused by $F$. oxysporum. Therefore, the objective of this study was to evaluate the effects of bentazon and bentazon/MCPA on Fusarium root rot and red clover growth under greenhouse conditions.

\section{MATERIAL AND METHODS}

\section{Greenhouse studies of the herbicide effects on Fusarium-disease}

This study was carried out in two independent experiments. Each experiment consisted of three rates of bentazon $\left(0,750\right.$ and $1500 \mathrm{~g}$ a.i. $\left.\mathrm{ha}^{-1}\right)$ and bentazon/MCPA $(0,750 / 720,1500 / 1440$ g a.i. ha-1) corresponding to 0 (control), field rate $(1 \mathrm{X})$ and twice of field rate (2X). The herbicide treatments were applied, with a compressed-air bicycle sprayer calibrated to deliver $200 \mathrm{~L} \mathrm{ha}^{-1}$ of sterile water solution, to seedlings at the two- to three-leaf trifoliate stage. (Ceballos et al., 2006).

For all experiments the plants were grown as describe by Ceballos et al. (2004; 2006) and Islam and Weil (1998). Two seeds, previously disinfected with a $0.5 \%$ sodium hypochlorite solution, were placed in each pot with allophanic soil (pH 6.1, 17\% organic matter, $31.6 \%$ sand, $53 \%$ silt, $15.4 \%$ clay) and were fertilized during the experiment (N 50; P 200, K 80 $\mathrm{mg} \mathrm{kg}^{-1}$ ).
$F$. oxysporum isolates were recovered and produced from diseased red clover plants, with evident vascular wilt symptoms, at the Carillanca Experimental Station in Temuco, Chile. Symptomatic root rot tissue was cut to $1 \mathrm{~cm}$ length, washed in distilled water, and soaked in a solution of $1 \% \mathrm{NaOCl}$ for $3 \mathrm{~min}$ (Akinsanmi et al., 2004). A $1.0 \mathrm{~cm}$ subsection was cut from each sterilized section and placed in Petri plates containing potato-dextrose agar $\left(39 \mathrm{~g} \mathrm{~L}^{-1}\right.$ of Difco PDA) and streptomycin sulphate $\left(100 \mathrm{mg} \mathrm{L}^{-1}\right)$. Plates were incubated at $25^{\circ} \mathrm{C}$ for $14 \mathrm{~d}$. The pathogenicity of isolates was assays on the Quiñequeli red clover cultivar, and the most pathogenic isolate, F127, was transferred to fresh PDA to complete the Koch's postulates and to continue the experiments (Ceballos et al., 2006). The specific characterization of this strain as $F$. oxysporum (IMI 390980) was provided by CABI Bioscience Identification Services, UK Centre (Egham). Inoculum was produced according to methods employed by Sanogo et al. (2000) and Ceballos et al. (2006). An agar plug, $5 \mathrm{~mm}$ diameter of selected isolate, was transferred from the colony of each isolate to PDA-plates and incubated at $22^{\circ} \mathrm{C}$. After $14 \mathrm{~d}$, conidia were harvested by adding $15 \mathrm{~mL}$ of sterile distilled water to each plate and gently scraping the medium surface with a paint brush. The number of conidia was determined with a hemacytometer.

The inoculum consisted of two levels, 0 (untreated plants) and level $1(5 \mathrm{~mL}$ of $2.5 \times 10^{6}$ spores $\left.\mathrm{m} \mathrm{L}^{-1}\right)$ and was applied, 15 $\mathrm{d}$ after herbicide treatments, by injection into the root zone of the aseptically grown plants at the two to three-leaf trifoliate stage. Temperature was $20-25^{\circ} \mathrm{C}$ between night and day respectively and light was supplemented with $1000 \mathrm{w}$ lamps for $16 \mathrm{~h}$. 
Pots were watered regularly on the surface throughout the experiment to ensure adequate soil moisture. Seedlings were carefully harvested at 20 and $30 \mathrm{~d}$ after herbicide treatment and washed under running tap water. Root length, seedling height, crown diameter and dry weight of shoots and roots were measured.

The effects of herbicides on fusarium pathogenicity and plant phytotoxicity were assessed on a scales proposes by Ceballos et al. (2006). Fusarium pathogenicity the scale was from 1 to 4 , where $1=$ completely healthy root tissue; $2=$ a few superficial dark-brown lesions of root tissue; 3 = extended superficial dark-brown lesions of root tissue and $4=$ necrotic root or tissue death. For herbicide phytotoxicity on red clover plants scale was from $1=$ no visible damage to $5=$ complete plant death, with symptoms that included chlorosis, leaf necrosis, and stunted growth (Ceballos et al., 2004, Ceballos et al., 2006). The root disease severity index (RDSI) and foliage damage index (FDI), were calculated by according to Vettraino et al. (2003) and Ceballos et al. (2006).

\section{Effects of herbicides on in vitro mycelial growth}

This study was carried out at optimal nutritional conditions for mycelial growth of F. oxysporum (Sanogo et al., 2000). Potato-dextrose agar was amended with the commercial formulation of bentazon and bentazon/MCPA at $0,1 \mathrm{X}$ and $2 \mathrm{X}$ rates. An agar plug, $5 \mathrm{~mm}$ diameter, was removed from the margin of the actively growing colony of F127 (2-wk-old cultures) placed in the center of herbicideamended plates, and incubated at $22^{\circ} \mathrm{C}$ with a $12 \mathrm{~h}$ photoperiod supplemented with a fluorescent light (Ceballos et al., 2006). Radial growth of mycelium from the center was recorded regularly over a month. The experiment was arranged in a completely randomized design with six replications for treatment.

\section{Effects of herbicides on in vitro conidial germination}

For conidial germination studies, conidia were obtained and collected by PDA cultures prepared as described in the fungal isolation section. Collected conidia were suspended in a solution of each herbicide treatment and incubated at $22^{\circ} \mathrm{C}$ in darkness. A treatment with conidia suspended in distilled water, at the same incubation conditions, was incorporated as control. After $6 \mathrm{~h}$ the number and proportion of germinated of conidia was determined under microscope with a hemacytometer (Sanogo et al., 2000). The proportion of germinated conidia was computed as the ratio of germinated conidia to observed conidia. The experiment was arranged in a completely randomized design with six replications for treatment.

\section{Data analysis}

The greenhouse trials were analyzed as completed randomized designs using a standard analysis of variance procedure. Treatments were considered fixed effects and reps within treatment were random and used for the error term. Means for root length, seedling height, crown diameter and dry weight of shoots and roots were separated using a Tukey's multiple range test at a $5 \%$ significance level. Since foliage damage and root rot severity were evaluated using rating scales, resulting in ordinal data. These were analyzed using the Kruskal-Wallis 
test, one-way analysis based on ranks, and group ranks were separated using the Conover-Inman test $(\mathrm{P} \leq 0.05)$ (Conover, 1999; Ceballos et al., 2004; Shah and Madden, 2004). Data of mycelial growth are given as a growth index obtained by dividing average diameter growth for the treatment by that for the corresponding control. Results were analyzed as a completely randomized design with treatments considered fixed effects and reps within treatment were random and used as the error term. Growth index means were separated by Dunnet's multiple comparisons test with a significance level of $\mathrm{P} \leq 0.05$. Conidial germination means were separated using Tukey's test $(\mathrm{P} \leq 0.05)$.

\section{RESULTS}

Although herbicides are applied to protect plants, they may also affect soil properties, microorganism, and host. These effects normally have little influence on plant growth. However, occasionally they cause temporary reduction in plat growth. This topic is complicated by the complex interactions of herbicide dose, formulation, tillage systems, environmental conditions, the plant pathogen, and the plant (Altman and Campbell, 1977; Altman and Rovira, 1989; Bollen, 1993). Furthermore, the timing of infection with the pathogen vs. that of the herbicide treatment can have a profound influence on the interaction. Thus, the literature often appears to be conflicting, but the apparent conflicts may be due to differences in one or more of the factors involved (Altman and Campbell, 1977; Bollen, 1993). Indirectly, through their strong effects on plants, herbicides can influence almost any process or interaction of the plant, including its susceptibility to plant diseases. In some cases, herbicides also have direct effects on plant pathogens (Bollen, 1993; Heydari et al., 1997; Heydari and Misaghi, 2003; Ceballos et al, 2006).

\section{F. oxysporum interaction with herbicide treatments}

Analysis of variance indicated that the bentazon - F. oxysporum interaction was statistically significant for root dry weight, and that the effects of these factors were not independent during the experimental period. For plant height, root length and shoot dry weight this interaction was not significant, but separately herbicide rate and inoculum level has a significant effect on these plant-growth parameters (Table 1). Crown diameter was not affected by herbicide rate, inoculum level or the interaction among these factors.

The interaction of bentazon rate and $F$. oxysporum inoculums level for root dry weight was statistically significant, indicating that bentazon rates and inoculums levels were not independent during the experiment. Across the 20 and 30 days evaluations, the mean reduction in root dry weight due to $F$. oxysporum alone was $37 \%$, compared to control, and the combination of reduced root dry weight by 42 and $49 \%$ at the $1 \mathrm{X}$ and $2 \mathrm{X}$ rates, respectively, in comparison with the mean of the untreated plants (Table 2). However, the reduction due to bentazon and $F$. oxysporum was different from bentazon alone for the $1 \mathrm{X}$ rate at 20 days only (Tukey's test, $\mathrm{P} \leq 0.05$ ) (Table 2).

Plants treated with bentazon had $17 \%$ and $19 \%$ reduction in plant height at 20 days for $1 \mathrm{X}$ and $2 \mathrm{X}$ rate respectively, compared to the untreated plants (Table 1). 
Table 1: Bentazon effect on plant height, root length and shoot dry weight of red clover plants.

\begin{tabular}{lccc}
\hline Rates $^{\text {a }}$ & $\begin{array}{c}\text { Plant height } \\
(\mathbf{c m})\end{array}$ & $\begin{array}{c}\text { Root length } \\
(\mathbf{c m})\end{array}$ & $\begin{array}{c}\text { Shoot dry weight } \\
(\mathbf{m g})\end{array}$ \\
\hline $20 \mathrm{~d}$ & & & \\
Control & $20,8 \mathrm{a}^{\mathrm{b}}$ & $20,7 \mathrm{~b}$ & $247,1 \mathrm{a}$ \\
$1 \mathrm{X}$ & $17,3 \mathrm{ab}$ & $21,6 \mathrm{~b}$ & $174,1 \mathrm{ab}$ \\
$2 \mathrm{X}$ & $16,8 \mathrm{~b}$ & $26,4 \mathrm{a}$ & $151,1 \mathrm{~b}$ \\
\hline $30 \mathrm{~d}$ & & \\
Control & $19,7 \mathrm{a}$ & $18,1 \mathrm{a}$ & $233,3 \mathrm{a}$ \\
$1 \mathrm{X}$ & $19,5 \mathrm{a}$ & $21,0 \mathrm{a}$ & $170,6 \mathrm{a}$ \\
$2 \mathrm{X}$ & $18,6 \mathrm{a}$ & $17,1 \mathrm{a}$ & $202,1 \mathrm{a}$ \\
\hline
\end{tabular}

${ }^{\mathrm{a}}$ Rate $1 \mathrm{X}$ : recommended; rate $2 \mathrm{X}$ : double recommended rate. ${ }^{\mathrm{b}}$ Values within a column, for each time period, followed by the same letter are not significantly different based on Tukey's test $(P \leq 0.05)$.

Table 2: Bentazon rate and Fusarium oxysporum interaction effects on red clover root dry weight (mg) at 20 and 30 days after herbicide treatment

\begin{tabular}{lccc}
\hline \multirow{2}{*}{ Inoculum level $^{\mathbf{a}}$} & \multicolumn{3}{c}{ Bentazon rate $^{\mathbf{b}}$} \\
\cline { 2 - 4 } & Control & $1 \mathrm{X}$ & $2 \mathrm{X}$ \\
\hline $20 \mathrm{~d}$ & & & \\
Untreated & $95,1 \mathrm{a}^{\mathbf{c}}$ & $52,5 \mathrm{c}$ & $48,6 \mathrm{c}$ \\
Inoculated & $65,3 \mathrm{~b}$ & $60,0 \mathrm{~b}$ & $40,8 \mathrm{c}$ \\
\hline $30 \mathrm{~d}$ & & & \\
Untreated & $103,1 \mathrm{a}$ & $55,5 \mathrm{~b}$ & $50,5 \mathrm{~b}$ \\
Inoculated & $59,5 \mathrm{~b}$ & $53,6 \mathrm{~b}$ & $59,9 \mathrm{~b}$ \\
\hline
\end{tabular}

${ }^{\text {a }}$ Inoculums level: Untreated: $5 \mathrm{~mL}$ of distilled water; Inoculated: $5 \mathrm{~mL}$ of $2.5 \times 10^{6}$ spores $\mathrm{mL}^{-1}$ conidial suspension of $F$. oxysporum. ${ }^{\mathrm{b}}$ Rate $1 \mathrm{X}$ : recommended rate; rate $2 \mathrm{X}$ : twice of recommended rate. ${ }^{\mathrm{c}}$ Values followed by the same letter are not significantly different based on Tukey's test $(P \leq 0.05)$.

However, this difference was significant for the $2 \mathrm{X}$ rate only. Root length at 20 days was $4 \%$ and $28 \%$ increased by $1 \mathrm{X}$ and $2 \mathrm{X}$ rate, respectively, but only the $2 \mathrm{X}$ rate was statistically different from the control plants (Table 1). Shoot dry weight at $20 \mathrm{~d}$ was $30 \%$ and $39 \%$ reduced by $1 \mathrm{X}$ and $2 \mathrm{X}$ rates, respectively, however again no significant difference was observed between the control and the $1 \mathrm{X}$ rate of bentazon. At 30 days there were no differences observed for plant height, root length and shoot dry weight between the control and either rate of bentazon. There was not significant bentazon/MCPA- $F$. oxysporum interactions for plant height and root length, demonstrating that the effects of both factors were independent 
throughout the experiment. Crown diameter was reduced by application of bentazon/MCPA $2 \mathrm{X}$ rate by $30 \%$ and $19 \%$ at 20 and $30 \mathrm{~d}$, respectively (Table 3 ), but this reduction was statistically significant only at $20 \mathrm{~d}$. Plants treated with $2 \mathrm{X}$ rate of bentazon/MCPA also had $45 \%$ and $41 \%$ reduction in plant shoot dry weight at 20 and $30 \mathrm{~d}$, respectively, compared with untreated plants (Table 3). F. oxysporum inoculation significantly affected crown diameter, shoot dry weight and root dry weight. Crown diameter of red clover was reduced 17 and $5 \%$ at 20 and $30 \mathrm{~d}$ respectively, compared with untreated plants (Table 4). However, this reduction was statistically significant at 20 days only $(\mathrm{P} P \leq 0.02)$. Shoot dry weight of plants inoculated with $F$. oxysporum was reduced 37 and $29 \%$ at 20 and $30 \mathrm{~d}$ respectively and plant root dry weight was reduced 41 and $35 \%$ at 20 and $30 \mathrm{~d}$, respectively, compared to the untreated control (Table 4).

Table 3: Bentazon/MCPA effect on crown diameter, shoot and root dry weight of red clover plants.

\begin{tabular}{lccc}
\hline Rates $^{\mathrm{a}}$ & $\begin{array}{c}\text { Crown diameter } \\
(\mathbf{m m})\end{array}$ & $\begin{array}{c}\text { Shoot dry weight } \\
(\mathbf{m g})\end{array}$ & $\begin{array}{c}\text { Root dry weight } \\
(\mathbf{m g})\end{array}$ \\
\hline $20 \mathrm{~d}$ & & & \\
Control & $2,7 \mathrm{a}^{\mathrm{b}}$ & $247,1 \mathrm{a}$ & $80,2 \mathrm{a}$ \\
$1 \mathrm{X}$ & $1,7 \mathrm{~b}$ & $132,1 \mathrm{~b}$ & $37,2 \mathrm{~b}$ \\
$2 \mathrm{X}$ & $1,9 \mathrm{~b}$ & $136,7 \mathrm{~b}$ & $40,0 \mathrm{~b}$ \\
\hline $30 \mathrm{~d}$ & & & \\
Control & $2,1 \mathrm{a}$ & $233,4 \mathrm{a}$ & $76,7 \mathrm{a}$ \\
$1 \mathrm{X}$ & $1,7 \mathrm{a}$ & $202,8 \mathrm{a}$ & $48,0 \mathrm{~b}$ \\
$2 \mathrm{X}$ & $1,7 \mathrm{a}$ & $138,2 \mathrm{~b}$ & $37,5 \mathrm{c}$ \\
\hline
\end{tabular}

${ }^{\mathrm{a}}$ Rate $1 \mathrm{X}$ : recommended rate; rate $2 \mathrm{X}$ : twice of recommended rate. ${ }^{\mathrm{b}}$ Values followed by the same letter are not significantly different based on Tukey's test $(P \leq 0.05)$.

Table 4: Fusarium oxysporum effect on crown diameter, shoot and root dry weight of red clover plants.

\begin{tabular}{lccc}
\hline Inoculums level $^{\mathrm{a}}$ & $\begin{array}{c}\text { Crown diameter } \\
(\mathbf{m m})\end{array}$ & $\begin{array}{c}\text { Shoot dry weight } \\
(\mathbf{m g})\end{array}$ & $\begin{array}{c}\text { Root dry weight } \\
(\mathbf{m g})\end{array}$ \\
\hline $20 \mathrm{~d}$ & & & \\
Untreated & $2,3 \mathrm{a}$ & $210,2 \mathrm{a}$ & $66,0 \mathrm{a}$ \\
Inoculated & $1,9 \mathrm{~b}$ & $133,3 \mathrm{~b}$ & $38,9 \mathrm{~b}$ \\
\hline $30 \mathrm{~d}$ & & & \\
Untreated & $1,9 \mathrm{a}$ & $223,4 \mathrm{a}$ & $68,0 \mathrm{a}$ \\
Inoculated & $1,8 \mathrm{a}$ & $159,4 \mathrm{~b}$ & $44,3 \mathrm{~b}$ \\
\hline
\end{tabular}

${ }^{a}$ Inoculums level: Untreated: $5 \mathrm{~mL}$ of distilled water; Inoculated: $5 \mathrm{~mL}$ of $2.5 \times 10^{6}$ spores $\mathrm{mL}^{-1}$ conidial suspension of $F$. oxysporum. Values followed by the same letter, for each parameter and time, are not significantly different based on Tukey's test $(P \leq 0.05)$. 
At $30 \mathrm{~d}$ the interactions of bentazon/MCPA-Fusarium to crown diameter and shoot dry weight were significant, indicating that bentazon/MCPA rates and inoculum levels were not independent of each other in this experimental period. Compared with untreated plants, crown diameter was reduced 43 and $40 \%$ at the $1 \mathrm{X}$ and
$2 \mathrm{X}$ rate, respectively, by bentazon/MCPA in presence of $\mathrm{F}$. oxysporum inoculation (Table 5).

Fusarium-inoculated plants had 39\% and $57 \%$ reduction in plant shoot dry weight with $1 \mathrm{X}$ and $2 \mathrm{X}$ of bentazon/MCPA rates in the presence of F. oxysporum inoculum compared to untreated control (Table 5).

Table 5. Bentazon/MCPA rate and Fusarium oxysporum inoculation interaction effects on red clover crown diameter and shoot dry weight at 30 days following herbicide treatment.

\begin{tabular}{lccc}
\hline Inoculums level $^{\mathbf{a}}$ & \multicolumn{3}{c}{ bentazon/MCPA rate $^{\mathbf{b}}$} \\
\hline Crown diameter $(\mathrm{mm})$ & Control & $1 \mathrm{X}$ & $2 \mathrm{X}$ \\
\cline { 2 - 4 } Untreated & $2,8 \mathrm{a}^{\mathrm{c}}$ & $1,8 \mathrm{~b}$ & $1,8 \mathrm{~b}$ \\
Inoculated & $1,8 \mathrm{~b}$ & $1,6 \mathrm{c}$ & $1,7 \mathrm{~b}$ \\
\hline Shoot dry weight $(\mathrm{mg})$ & & & \\
Untreated & $279,2 \mathrm{a}$ & $235,7 \mathrm{ab}$ & $155,6 \mathrm{c}$ \\
Inoculated & $267,6 \mathrm{a}$ & $169,8 \mathrm{~b}$ & $120,5 \mathrm{c}$ \\
\hline
\end{tabular}

${ }^{\mathrm{a}}$ Inoculums level: Untreated: $5 \mathrm{~mL}$ of distilled water; Inoculated: $5 \mathrm{~mL}$ of $2.5 \times 10^{6}$ spores $\mathrm{mL}^{-1}$ conidial suspension of $F$. oxysporum. ${ }^{\mathrm{b}}$ Rate $1 \mathrm{X}$ : recommended rate; rate $2 \mathrm{X}$ : twice of recommended rate.

${ }^{\mathrm{c}}$ Values followed by the same letter are not significantly different based on Tukey's test $(P \leq 0.05)$.

\section{Foliage damage and root rot indices}

The foliage damage index (FDI) displayed statistically significant differences for inoculated plants; this response was not independent of the herbicide application rate or days after treatment (Figure 1B). At $20 \mathrm{~d}$, bentazon significantly increased FDI at the $2 \mathrm{X}$ rate, but at $30 \mathrm{~d}$, differences at the $2 \mathrm{X}$ rate were not statistically significant (Figure 1A). Detrimental effects were observed on foliage of red clover plants with application of bentazon/MCPA throughout the experimental period for all rates (Figure 1B). At $20 \mathrm{~d}$ the $\mathrm{F}$. oxysporum plus $1 \mathrm{X}$ bentazon/MCPA rate caused the most phytotoxic effect and the
FDI was $120 \%$ higher relative to untreated plants (Figure 1B).

At 30 days after bentazon application the root rot severity did not vary significantly among treatments (Figure 1C). However, the inoculated plants $20 \mathrm{~d}$ after bentazon application demonstrated an increased root disease severity index (RDSI). However not significant differences were observed between rates (Figure 1). The RDSI of plants treated with the herbicide mixture bentazon /MCPA were significantly affected throughout the experimental period (Figure 1D). The inoculated plants treated with $1 \mathrm{X}$ and $2 \mathrm{X}$ rates of 

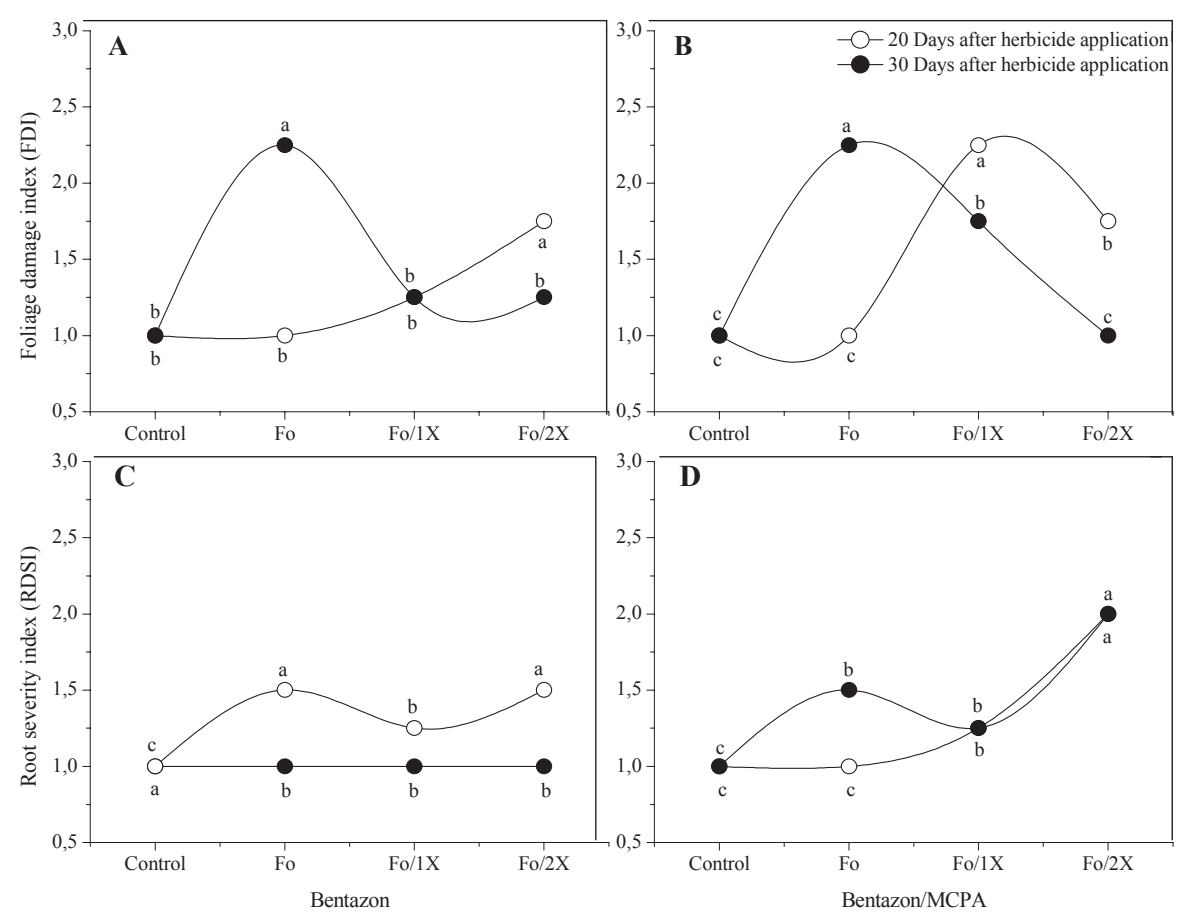

Figure 1: Foliage damage and root disease severity index from bentazon-Fusarium oxysporum and bentazon/MCPA-Fusarium oxysporum treatments on red clover plants.

${ }^{a}$ Treatments: Control: untreated, $\mathrm{F}_{0}$ : Fusarium inoculum only, $\mathrm{F}_{0} / 1 \mathrm{X}$ : Fo + Bentazon at $1 \mathrm{X}$ rate, $\mathrm{F}_{0} / 2 \mathrm{X}$ : Fo + Bentazon at $2 \mathrm{X}$ rate. ${ }^{\mathrm{b}}$ Values, for each time period, followed by the same letter are not significantly different based on Conover-Inman's test $(P \leq 0.05)$.

bentazon/MCPA had $25 \%$ and $100 \%$ increases in their RDSI, respectively, compared to the untreated control (Figure 1D).

\section{Mycelial growth and conidia germination effects}

Mycelial growth was slightly inhibited by both $1 \mathrm{X}$ and $2 \mathrm{X}$ rates of bentazon (Figure 2). The herbicide mixture bentazon /MCPA did not affect the mycelial growth with $1 \mathrm{X}$ rate, however, the $2 \mathrm{X}$ rate showed the strongest inhibition of $F$. oxysporum mycelial growth (Figure 2).
Conidial germination of $F$. oxysporum in a bentazon solution showed no significant differences compared to the control at all herbicide rates.

On the contrary, the germination of conidia was significantly reduced by bentazon/MCPA at the highest rate and a significant dose-response effect was observed; the suspended conidia in bentazon/MCPA solution at $1 \mathrm{X}$ and $2 \mathrm{X}$ rates had $28 \%, 33 \%$ and $40 \%$ reduction in germination, respectively, compared to the untreated control plants. 


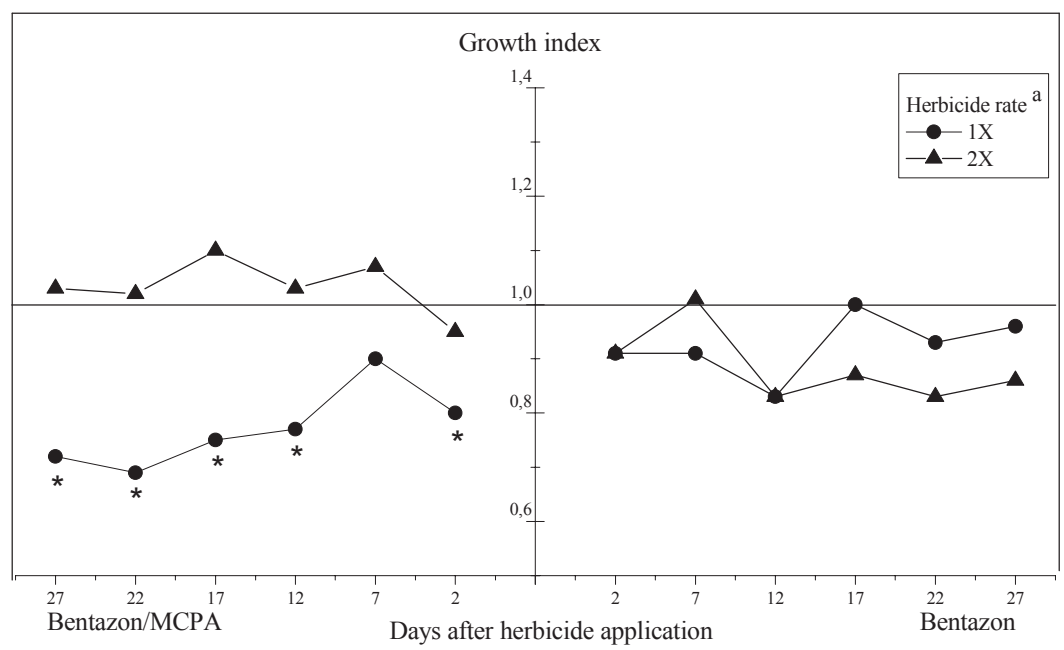

Figure 2: Mycelial growth of Fusarium oxysporum on agar-potato dextrose amended

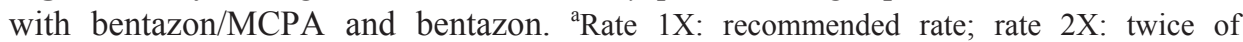
recommended rate. ${ }^{*}$ Indicates significant difference with corresponding control according to Dunnet-test $(\mathrm{P}<0.05)$.

\section{DISCUSSION}

In addition to the desired weed control, herbicides can result in a modification of disease development, generally as a result of the interaction between direct effects on the pathogen and indirect effects via plant-mediated responses (Altman and Rovira, 1989; Bollen, 1993; Liu et al., 1997, Sanogo et al., 2000). The range of herbicide concentrations used was selected to represent what would be encountered in production fields at the recommended rate $(1 \mathrm{X})$ and an accidental overlap of spray coverage (2X). The pathogen would be subjected to herbicide adsorbed directly from the spray solution and that from residues the plant or taken up and translocated from roots or foliage (Sanogo et al., 2000).

The present investigation showed that when the direct effect of bentazon and
bentazon/MCPA on $F$. oxysporum was examined, bentazon had no effect on spore germination (Figure 3) and some, not significant, inhibitory effects on myceliar growth (Figure 2). On the other hand, bentazon/MCPA strongly inhibited spore germination and decreased mycelial development, at the highest rate. In our previous study of the effect of application of MCPA on $F$. oxysporum, herbicide alone had negligible effect on spore germination of $F$. oxysporum (Ceballos et al., 2006). Other studies with Fusarium spp. have also shown inhibitory responses with MCPA (Grossbard, 1976; Ceballos et al., 2006) but stimulation of Fusarium spp. growth by some herbicides such as has also been reported (Mussa and Rusell, 1977). Ceballos et al. (2006) in a greenhouse study with the same herbicide 
rate showed that MCPA increased fusarium root rot severity to red clover seedlings. The effect of a herbicide on disease levels is not always the same as its effect on pathogen in vitro growth studies (Sanogo et al., 2000), because direct contact between the pathogen and the herbicide would not be as likely to occur under complex natural environmental conditions. Herbicide stress weakens and predisposes plants to rapid fungal colonization (Sanogo et al., 2000; Ceballos et al., 2006), and could explain the significant increase in disease severity and pathogen isolation frequency following application of some herbicides (Dissanayake et al., 1998; Sanogo et al., 2000).

The influence of bentazon and bentazon/MCPA on infection by $F$. oxysporum on red clover has not been previously reported. Bentazon reduced the root dry weight and the bentazon/MCPA decreased crown diameter and shoot dry weight. Although comparisons could be made with other herbicides, where agronomic parameters were decreased (Ceballos et al., 2006).

As in a previous study of the MCPA effect on fusarium infection (Ceballos et $a l ., 2006)$, the application of bentazon and bentazon/MCPA resulted in a reduction of shoot growth and crown diameter. This topic is complicated by the intricate interactions among herbicide dose, formulation, tillage systems, environmental conditions, the plant pathogen, and the plant. Furthermore, the timing of infection with the pathogen vs. that of the herbicide treatment can have a profound influence on the interaction. Although the literature often appears to be conflicting, the apparent conflicts may be due to differences in one or more of the factors involved.

\section{CONCLUSION}

The effects of $F$. oxysporum inoculation and herbicide treatments seem be operating in different directions during the experimental period. $F$. oxysporum effect increases over time as disease progresses, and the effects of the herbicide may be reduced eventually as the plants outgrow the detrimental effects. However in this study, as in earlier investigations (Ceballos et al., 2004; Ceballos et al., 2006) the herbicide treatment in red clover plants infected with $F$. oxysporum increased plant disease. However these results necessarily must be validated with field experiments.

\section{ACKNOWLEDGEMENT}

The financial support of this research was provided by FONDECYT 1020297 and CONICYT PBCYT PSD05 Projects.

\section{REFERENCES}

AFIPA. 2002. Manual fitosanitario Asociación de distribuidores de plaguicidas, Santiago. Chile.

Akinsanmi, O. A., Mitter, V., Simpfendorfer, S., Backhouse, D., Chakraborty, S. 2004. Identity and pathogenicity of Fusarium spp. isolated from wheat fields in Queensland and northern New South Wales. Australian Journal of Agricultural Research. 55, 97-107.

Altman, J., Campbell, C. L. 1977. Effect of Herbicides on Plant Diseases. Annual Review of Phytopathology. 15, 361-385.

Altman, J., Rovira, A. D. 1989. HerbicidePathogen Interactions in Soil-Borne Root Diseases. Canadian Journal of Plant PathologyRevue Canadienne De Phytopathologie. 11, 166172 . 
Bollen, G. J. 1993. Mechanisms involved in nontarget effects of pesticides on soil-borne pathogens, p. 281-301, In J. Altman, ed. Pesticide interactions in crop production: beneficial and deleterious effects. CRC Press, Boca Raton.

Bradshaw, L., Barret, M., Poneleit, C. 1992. Physiological basis for differential bentazon susceptibility among corn (Zea mays L.) inbreds. Weed Science. 40, 522-527.

Carson, M. L., Arnold, W. E., Todt, P. E., 1991. Predisposition of soybean seedlings to Fusarium root-rot with trifluralin. Plant Disease. 75, 342-347.

Ceballos, R., Palma, G., Brevis, H., Ortega, F., Quiroz. A. 2004. The effect of five postemergence herbicides on red clover shoot and root growth in greenhouse studies. Phytoprotection. 85, 153-160.

Ceballos, R., Palma, G., Perich, F., Pardo, F., Quiroz, A. 2006. Influence of MCPA on Fusarium oxysporum root rot and red clover growth under controlled greenhouse conditions. Phytoprotection. 87, 9:15.

Conover, W. J. 1999. Practical non-parametric statistics. 3rd ed. Wiley, New York; Chichester.

Conrad, J. D., Stritzke, J. F. 1980. Response of arrow leaf clover to post-emergence herbicides. Agronomy Journal. 72, 670-672.

Coulman, B. E., Lambert, M. 1995. Selection for Resistance to Root-Rot Caused by Fusarium spp in Red-Clover (Trifolium pratense L). Canadian Journal of Plant Science. 75, 141-146.

Dann, E. K., Diers, B. W., Hammerschmidt, R. 1999. Suppression of Sclerotinia stems rot of soybean by lactofen herbicide treatment. Phytopathology. 89, 598-602.

Dissanayake, N., Hoy, J. W., Griffin, J. L. 1998. Herbicide effects on sugarcane growth, pythium root rot, and Pythium arrhenomanes. Phytopathology. 88, 530-535.
Fleming, A. A., Banks, P. A., Legg, J. G. 1988. Differential response of maize inbreds to bentazon and other herbicides. Canadian Journal of Plant Science. 68, 501-507.

Galdames, R. G. 1991. Enfermedades fungosas, p. 45-51, In A. B. Torres and J. C. L. Bumant, eds. Producción y utilización de trébol rosado (Trifolium pratense L.). INIA-Remehue, Osorno, Chile.

Grabinska-Sota, E., Wisniowska, E., Kalka, V. 2003. Toxicity of selected synthetic auxines 2,4-D and MCPA derivatives to broad-leaved and cereal plants. Crop Protection. 22, 355-360.

Grossbard, E. 1976. Effects on the soil microflora, p. 99-147, In L. J. Audus, ed. Herbicides: physiology, biochemistry, ecology, $2^{\text {nd }}$ ed. Academic press.

Hess, F. D. 1993. Herbicide effects on plant structure, physiology, and biochemistry, p. 13-34, In J. Altman, ed. Pesticide interactions in crop production: beneficial and deleterious effects. CRC Press, Boca Raton.

Heydari, A., Misaghi, I. J. 2003. The role of rhizosphere bacteria in herbicide-mediated increase in Rhizoctonia solani-induced cotton seedling damping-off. Plant and Soil. 257, 391396.

Heydari, A., Misaghi, I. J., McCloskey, W. B. 1997. Effects of three soil-applied herbicides on populations of plant disease suppressing bacteria in the cotton rhizosphere. Plant and Soil. 195, 7581.

Islam, K. R., Weil, W. B. 1998. Microwave irradiation of soil for routine measurement of microbial biomass carbon. Biology and Fertility of Soils. 27, 408-416.

Kuds, P., Streibig, J. 2003. Herbicide a two edged sword. Weed Research. 43, 90-102. 
Leath, K. T. 1985. General Disease, p. 205-233, In N. Taylor, ed. Clover Science and Technology, Madison, WI.

Liu, L., Punja, Z. K., Rahe, J. E. 1997. Altered root exudation and suppression of induced lignification as mechanisms of predisposition by glyphosate of bean roots (Phaseolus vulgaris L.) to colonization by Pythium spp. Physiological and Molecular Plant Pathology. 51, 111-127.

Liu, S. H., Quick, W. A., Hsiao, A. I., Streibig, J. C. 1994. Effect of MCPA on the phytotoxicity of imazamethabenz-methyl applied to wild oats (Avena fatua L). Weed Research. 34, 425-431.

Mussa, A., Russell, P. 1977. The influence of pesticides and herbicides on the growth and virulance of Fusarium solani f.sp. phaseoli. Journal of Agricultural Science. 88, 705-709.

Sanogo, S., Yang, X. B., Scherm, H. 2000. Effects of herbicides on Fusarium solani f. sp glycines and development of sudden death syndrome in glyphosate-tolerant soybean. Phytopathology. 90, 57-66.

Shah, D. A., Madden, L. V. 2004. Nonparametric analysis of ordinal data in designed factorial experiments. Phytopathology. 94, 33-43.

Steiner, J. J., Alderman, S. C. 1999. Red clover seed production: V. Root health and crop productivity. Crop Science. 39, 1407-1415.
Tharp, B. E., Kells, J. J. 2000. Effect of soilapplied herbicides on establishment of cover crop species. Weed Technology. 14, 596-601.

Tomlin, C. 1995. The Pesticide manual. A world compendium. $10^{\text {th }}$ ed. British Crop Protection Council, Farnham, UK.

Venuto, B. C., Smith, R. R., Grau, C. R. 1995. Virulence, Legume Host-Specificity, and Genetic Relatedness of Isolates of Fusarium oxysporum from Red-Clover. Plant Disease. 79, 406-410.

Venuto, B. C., Smith, R. R., Grau, C. R. 1996. Temperature dependent reaction and selection response of two red clover populations to fusarium wilt. Crop Science. 36, 1477-1481.

Venuto, B.C., Smith, R. R., Grau, C. R. 1999. Selection for resistance to Fusarium wilt in red clover. Canadian Journal of Plant Science. 79, 351-356.

Vettraino, A. M., Belisario, A., Maccaroni, M., Vannini, A. 2003. Evaluation of root damage to English walnut caused by five Phytophthora species. Plant Pathology. 52, 491-495.

Wu, C., Wang, C. 2003. Physiological Study on Bentazon Tolerance in Inbred Corn (Zea mays). Weed Technology. 17, 565-570. 